\title{
Implementation of Total Quality Management as Efforts to Improve Quality of Primary School Education Services During the COVID-19 Pandemic Period
}

\author{
Sowiyah, University of Lampung, Indonesia, sowi.unila@gmail.com ORCID: 0000-0003-4597-8152
}

\begin{abstract}
The COVID-19 pandemic has forced offline learning into online learning that utilizes technology. Although the system has changed, the quality of education services needs to be improved. One of the method is using Total Quality Management (TQM) in elementary schools. This study aims to know the quality of education services during this pandemic and analyze the effect of implementing TQM to improve the education services. The study was conducted with a quantitative descriptive design. Data was collected using a questionnaire filled by parents of students and teachers. The data were analyzed using Chi Square. The results of the data analysis showed that during this pandemic, the quality of education services was in the 'sufficient' category. However, when the TQM implementation was carried out, the service quality improved to the 'good' category. So it can be said that the application of TQM can improve the education services in schools.
\end{abstract}

Keywords: Pandemic COVID-19, Total Quality Management, Primary schools $\begin{array}{lll}\text { Received: 15.12.2020 } & \text { Accepted: 19.01.2021 } & \text { Published: 09.02.2021 }\end{array}$

\section{INTRODUCTION}

The beginning of 2020 was marked by the emergence of coronavirus disease (COVID-19) which infected millions of people in various parts of the world, even causing death (Lin et al., 2020; Shereen, et al., 2020; Wahyono, Husamah, and Budi, 2020). And the World Health Organization (WHO) has also established COVID-19 as a global pandemic (Mahase, 2020; Watkins, 2020). In an effort to prevent transmission, the rules of distancing social health protocols are applied. With this regulation, the public is required to limit their interactions. Of course it will greatly affect all human activities in various fields, without exception in the field of education (World Health Organization, 2020; Anderson, 2020; Yan, 2020; Zhang, Wang, Yang, and Wang, 2020). This is because the educational service process always involves a lot of interaction between teacher and teacher, teacher and student, and students and students. These interactions will increase the risk of spreading the virus.

Policies taken by governments in all countries affected by COVID-19, including Indonesia, in the field of education in order to decide on the spread of the corona virus are temporarily dismissing learning and teaching activities in schools (Wahyono, Husamah, and Budi, 2020). This policy seems appropriate, but on the other hand, this policy raises new problems because it is not possible to dismiss educational activities for a long time. Therefore, innovation in carrying out learning and teaching activities is needed. One effort that can be made is to utilize technology to conduct remote learning and teaching activities (online learning) (Aderholt, 2020; UNESCO, 2020; Horn, 2020; Indonesian Minister of Education and Culture Regulation No. 3 of 2020). Online learning can be used as a solution for educational services during the pandemic. This is because in the learning system, students are still able to interact, even if not directly. This learning system is also considered practical because it can utilize the gadget that is owned.

However, in reality the practicality of this online learning system does not necessarily facilitate students and teachers to carry out activities that they should, especially for elementary school students. There needs to be assistance of parents when the instruction from the teacher has been given, either in the form of delivering material or giving assignments. Of course this will be one of the many challenges of technology-based learning for educational institutions (schools) to continue providing quality educational services for their students. For this reason, there needs to be good coordination between schools, teachers, parents, and students themselves.

To maintain the quality of education services from classroom learning methods to online-based learning, teachers will have a very important role (Zein, 2016; Zacharo, Marios, \& Dimitra, 2018). Teachers need to have the ability and knowledge in using digital technology so that it will support in preparing learning material that can later be accessed by students. However, it also needs to be supported by adequate supporting facilities for the implementation of distance learning activities. This is a problem that is often faced by educational institutions in Indonesia. The results of interviews conducted with 20 
elementary school teachers showed that they found it difficult to use technology, there were even three teachers who really could not use it at all. And the results of a survey of 10 elementary schools indicate inadequate facilities for conducting distance learning for teachers. Of course this will greatly affect how the material will be conveyed to students. However the conditions are, students and parents can be said to be consumers who want good quality educational services. So that their level of satisfaction with the services provided will illustrate the quality of education services that schools provide. To improve the quality of education services, a service quality assurance system needs to be implemented, one of which is Total Quality Management (TQM).

\section{Technology Based Learning}

Technology-based learning is a learning process by utilizing information technology advancements (Putra, 2009; Muhson, 2010). Usually this learning is better known as online-based learning. This learning has become very useful during the current pandemic. The development of technology has undeniably influenced the educational process that was initially conventional (Muhson, 2010). Learning now is not fixed in one place and requires teachers and learners to be in the same place. Learning can now be done even though distance has been separated because it is supported by modern devices such as computers, smartphones, internet networks, and others (Bali, 2019; Temelli, Şahin, and Kartal, 2020; Lever-Dufy \& Mcdonald, 2008). According to Putra (2009), there are several media that can be used in information technology-based learning, namely 1) internet (e-learning, distance learning, web base learning); 2) intranet; 3) mobile phone; and 4) flashdisk. These media in general can be used in the learning process. Even if the teacher has high skills and creativity, the use of the media will become more optimal. In information technology-based learning media, teachers can enter materials and assignments at one time making it easier for students to access them (Putra, 2009).

In technology-based learning, teachers need various preparations. Starting from the design of learning and learning materials, which are tailored to the technology that will be used. So in this way, learning will become more effective (Kuş̧̧u \& Arslan, 2015). To be able to maximize this learning system, training is needed so that teachers can integrate with technology (Ismajli, Bytyqi-Damoni, Shatri, and Ozogul, 2020). Such training programs are indispensable for the continuous development of teacher professionalization (Sugar, 2005). Profram training also provides support for teachers to increase knowledge and provide innovations for teachers to apply technology in classroom learning (ChanLin, 2008; Jang, 2010; Glazer \& Hannafin, 2008; Glazer, Hannafin \& Song, 2005; Niess, 2005). So that teachers will be able to organize learning and teaching activities that are more motivating for students. Of course this will be able to increase student achievement better (Spears, 2012; Putra, 2009; Harris, Al-Bataineh \& Al-Bataineh, 2016; Cavanaugh, Dawson \& Ritzhaupt, 2011).

\section{Total Quality Management (TQM)}

TQM is the application of quantitative methods and humanitarian knowledge to: 1) improve the materials and services that are input to the organization, 2) improve all important processes in the organization, and 3) improve efforts to meet the needs of users of products and services in the present and the future (Sallis, 2006; Tjiptono \& Diana, 2000). In the TQM system, all objects / facilities and everyone in the institution are really involved to improve the quality of service where customer satisfaction is an indicator (Sutarto, 2015; Bounds et al., 1994; George \& Weimerskirch, 1994). There are ten things that need to be understood and done in implementing TQM, namely 1) focus on customers (parents of students and students); 2) quality obsession, as an effort to meet quality standards, even exceeding quality standards; 3) scientific approach, related to decision making based on data; 4) long-term commitments, applied and made into a work culture; 5) teamwork, each division does not compete but support each other; 6) continuous improvement of the system, related to the quality of services and work systems; 7) education and training, to improve staff expertise and skills; 8) controlled freedom, related to employee involvement in decision making; 9) unity of objectives, related to the perception of equality between institutions and employees; and 10) involvement and empowerment, this can foster a sense of ownership of employees towards the institution by providing input as consideration in decision making (Goetsch and Davis, 2014). In addition, in an effort to improve the quality of education services, there are four principles that need to be applied, namely 1) plan based on objectives; 2) carry out based on the draft prepared; 3) checking and measuring the results of implementation; and 4) evaluating the results of the measurement results of the implementation (Goetsch and Davis, 2014; Arcaro, 1995; Bank, 1992). After the evaluation process, the process returns to the first stage, which is to plan again based on the evaluation results and objectives. Theoretically, the concept of TQM looks promising as a way to improve the quality of education services in schools. However, there is a need to test the concept in elementary 
schools in Indonesia. Therefore, this study was conducted to analyze the effect of implementing TQM in elementary schools.

\section{Relationship of Customer Satisfaction with the Quality of Education Services}

Customer satisfaction is the ultimate goal of service quality. Customer satisfaction has a close bond with service quality. Not fulfilled customer satisfaction can state the poor quality of services provided (Sutarto, 2015). Goetsch and Davis (2014) divide customers into two, namely internal customers and external customers. Internal customers can be interpreted as those who receive products or services but are in the same institution, while external customers are recipients of products / services that are outside the institution. In educational institutions, in this case the school, parents act as external customers. Whereas the teacher can act as an internal customer. Both types of customers can determine how high the quality of education services provided by schools as the organizing agency. Therefore, one way to improve the quality of education services is to analyze the needs of internal and external customers (Sutarto, 2015). Schools need to analyze what is desired by students' parents, the general public, the business world, and the industrial world who act as recipients of the product. This was also balanced by analyzing the needs of teachers, staff, and school principals to meet the target quality of education services (Sutarto, 2015; Mukhopadhyay, 2005).

\section{METHODS}

This research is a quantitative descriptive study with the aim to see an overview of the quality of education services and the effect of the application of TQM on the quality of education services in primary schools. While the method used is a survey method that has the main goal to be able to overcome research problems (Sugiyono, 2010; Arikunto, 2016). The research was carried out during the implementation of the distance learning system, from March 2020 to June 2020.

\section{Population and Sample}

The population is the whole of the research subjects who are in a certain region and time, while the sample is part of the population (Arikunto, 2016; Sugiyono, 2010). The population in this study is elementary schools, both private and public, located in the city of Bandar Lampung, Indonesia. While the school sample in this study is an elementary school that will implement TQM as an effort to improve the quality of education services in the COVID-19 pandemic condition in Bandar Lampung City, Indonesia. Based on the survey results, there is only one primary school that can be sampled because it meets the desired sample criteria. Participants involved in data collection are parents of students (as consumers) and teachers as the spearhead in providing educational services. The number of parents involved in the first survey was 60 people. For the second survey, there were 58 parents involved in filling the questionnaire. While the number of teachers involved in this study was 8 people.

\section{Data Collection Techniques}

Data obtained by filling out the questionnaire. The survey was conducted on parents before TQM was applied and after TQM was implemented. In detail, the data collection process can be seen in FIGURE 1. Survey I of the parents of students will produce data that describe the quality of educational services before TQM is applied (Data Ia). Whereas Data Ib, which is the result of Survey I data on teachers, will produce a picture of things that support and hinder the process of service delivery. Both of these data can be used as a complementary evaluation material. Quality of service prior to the implementation of TQM is illustrated by Data Ia while extracting in-depth information related to reasons about good or bad services can be obtained from Data Ib. So that improvements to management or implementation systems can be done based on these data. 


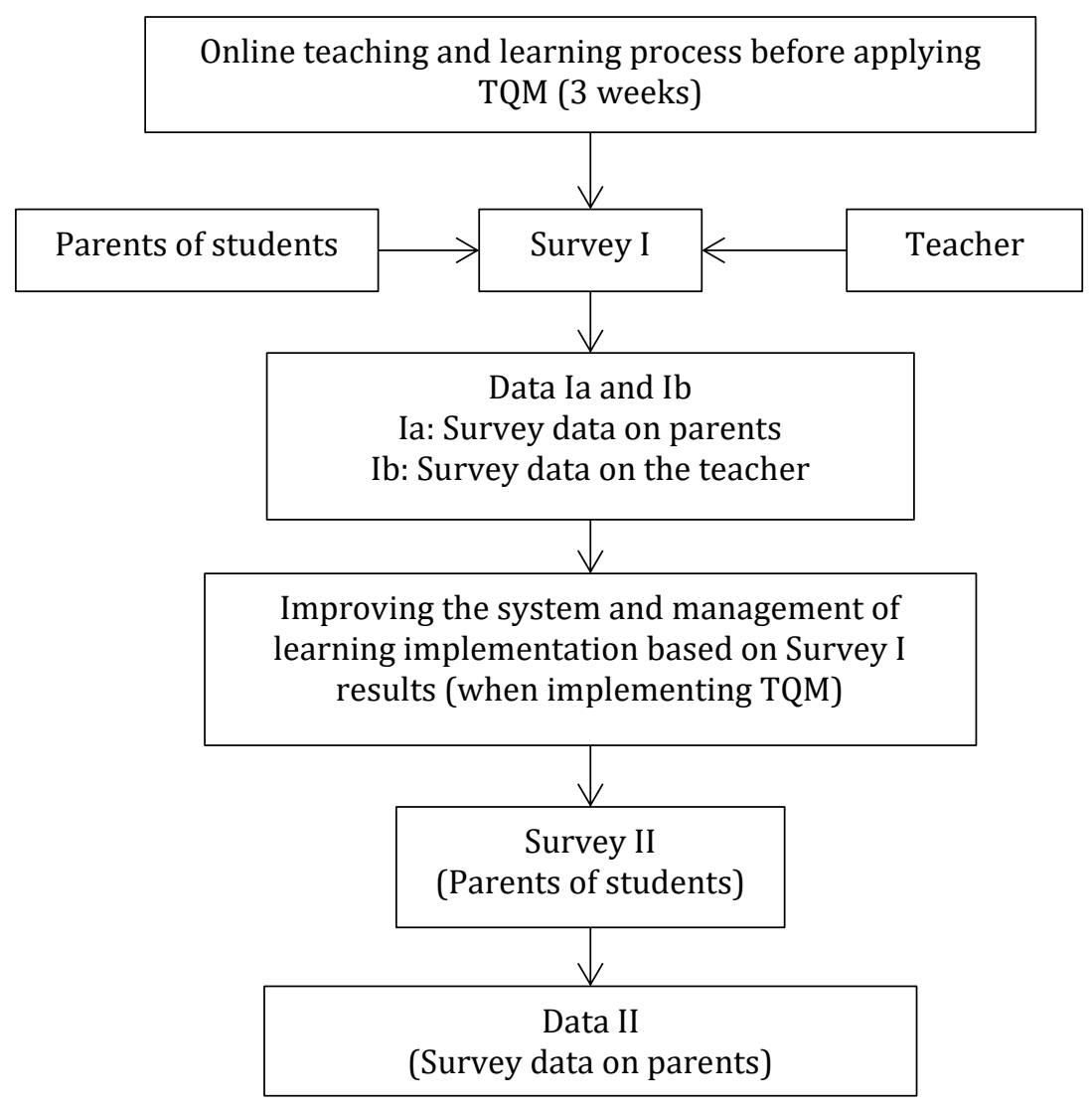

Figure 1. Research Data Collection Process

The description of service quality after TQM is applied is obtained from the completion of the second questionnaire (Survey II) by parents of students. Data from this survey (Data II) can illustrate how the quality of education services provided by schools after TQM is applied. From Data II, it will be seen how the influence of the application of TQM as an effort in improving the quality of education services.

\section{Data analysis}

Data from the filling out of the questionnaire were converted to numbers on a scale of 100. Descriptive conclusions refer to the classification of scores by Sugiyono (2010) which can be seen in Table 1 .

Table 1. Classification of Service Quality Assessment Through Questionnaires

\begin{tabular}{|l|l|}
\hline Skor & Criteria \\
\hline $\mathbf{8 1}-\mathbf{1 0 0}$ & Very Good \\
\hline $\mathbf{6 1}-\mathbf{8 0}$ & Good \\
\hline $\mathbf{4 1 - 6 0}$ & Enough \\
\hline $\mathbf{2 1 - 4 0}$ & Less \\
\hline $\mathbf{5 2 0}$ & Bad \\
\hline
\end{tabular}

For statistical analysis, Data Ia and Data II were analyzed by the T-test. However, before the T-test was carried out, both of the data groups had to be tested first. If both data are normally distributed, then the $\mathrm{T}$ test can be performed. However, if the two data groups or one data group is not normal, then the statistical analysis is done with Chi Square. If the significance value of the T test in both data is below the value of $\alpha$ (0.05), then it can be said that the application of TQM significantly influences the quality of education services. And conversely, if the significance value of the T test on both data is above the value of $\alpha(0.05)$, then it can be said that the application of TQM does not significantly influence the quality of education services. The reading criteria also apply to the Chi Square test. 


\section{RESULTS}

The online learning process is carried out according to the provisions of the Indonesian government. The implementation of the learning process without TQM is carried out for three weeks to see the responses of parents of students who act as customers. For three weeks, the teacher is directed to prepare learning materials and assignments for each meeting tailored to online learning. Survey I was conducted at the end of the third week by asking students' parents to fill out questionnaires related to service quality and teachers to fill conditions, support, and obstacles in implementing online learning processes. Data for filling out the questionnaire in Survey I and Survey II can be seen in Table 2.

Based on the data in Table 2, the level of satisfaction of the parents of students in Survey I is widely distributed in the quite good and good category with each percentage of $33 \%$ and $23 \%$. The remaining $6.67 \%$ felt that the education services provided were not good. The number of parents who feel the quality of educational services that provide good enough dominates with the number of 33 people. The mean score also shows that the level of satisfaction of students' parents as customers is still in the sufficient category. Of course this needs to be considered carefully and there needs to be deeper digging of information.

Efforts to extract more in-depth information were carried out by conducting interviews with several parents who assessed the quality of education services as being in sufficient and inadequate categories. The results of the interviews provide information that they feel that the content and manner of delivery of teachers is not as good as in class. The given assignment was considered too much so that it was very burdensome for students and parents of students. This is because during the pandemic, students' parents are forced to actively participate in helping guide their children in doing tasks based on the teacher's direction through learning media. So that this burdens the parents, moreover the task given is very excessive. They also felt the learning process was less effective by relying only on digital conference media because the teacher did not prepare the material well and gave more assignments. Constraints on the internet network did not escape being one of the factors that influence the assessment. Uneven quality of the internet network becomes an obstacle, especially for students who live in the suburbs. Resulting in poor audio and visual quality.

Table 2. Data of the Questionnaire Filling Out in Survey I and Survey II

\begin{tabular}{|c|c|c|c|c|}
\hline & Skor & Frequency & Percentage & Category \\
\hline \multirow{8}{*}{$\begin{array}{l}\text { Data Ia } \\
\text { (Survey I) }\end{array}$} & $81-100$ & 0 & $0,00 \%$ & Very good \\
\hline & $61-80$ & 23 & $38,33 \%$ & Good \\
\hline & $41-60$ & 33 & $55,00 \%$ & Enough \\
\hline & $21-40$ & 4 & $6,67 \%$ & Less \\
\hline & $\leq 20$ & 0 & $0,00 \%$ & Bad \\
\hline & Rerata & \multicolumn{3}{|l|}{59,93} \\
\hline & Maximum & \multicolumn{3}{|l|}{78,00} \\
\hline & Minimum & \multicolumn{3}{|l|}{40,00} \\
\hline & Skor & Frequency & Percentage & Category \\
\hline \multirow{8}{*}{$\begin{array}{l}\text { Data II } \\
\text { (Survey II) }\end{array}$} & $81-100$ & 4 & $1,72 \%$ & Very good \\
\hline & $61-80$ & 51 & $93,10 \%$ & Good \\
\hline & $41-60$ & 3 & $5,17 \%$ & Enough \\
\hline & $21-40$ & 0 & $0,00 \%$ & Less \\
\hline & $\leq 20$ & 0 & $0,00 \%$ & Bad \\
\hline & Rerata & \multicolumn{3}{|l|}{74,45} \\
\hline & Maximum & \multicolumn{3}{|l|}{85,00} \\
\hline & Minimum & \multicolumn{3}{|l|}{60,00} \\
\hline
\end{tabular}

Information gathering is also deepened by conducting a survey of teachers. This is done so that the incoming information becomes balanced between consumers and service providers (teachers). The survey was conducted by filling out a questionnaire whose contents covered several things, namely 
facilities and infrastructure, teacher knowledge, teacher skills, cooperation between teachers, institutional support, and coordination of leaders and teachers. Details of the results of a survey of teachers can be seen in Table 3. Aspects of facilities and infrastructure and institutional support need to be highlighted because most of the teachers consider that these aspects are obstacles for them. They considered that institutions demand good learning but are not matched by good facilities and support. In terms of facilities and infrastructure, teachers find it difficult to provide limited internet quotas, while schools do not provide internet connection. So they have to set expenses to be able to buy an adequate internet quota. This aspect also relates to aspects of skills and creativity, where the teacher wishes to create video content to give to students but does not have the supporting tools. So they are forced to use makeshift tools and makeshift rooms. In the aspect of institutional support that is also related to the mastery of teachers to the media. The teacher feels difficult in using learning media because they are not accustomed. So they were forced to use the best way through Whatsapp message media in delivering material. The use of the Zoom Cloud Meeting application, Google Classroom, Youtube, and other applications is not carried out optimally. This is because they are not familiar with the application and they are not familiar with the use of information technology. The teacher feels left by the institution so that the evaluation on aspects of institutional support is lacking.

Table 3. Survey Results for Teachers

\begin{tabular}{|l|l|l|l|}
\hline Assessment criteria & Assessment category & Frequency & Percentage \\
\hline \multirow{3}{*}{ Facilities and infrastructure } & Baik & 1 & $12.50 \%$ \\
\cline { 2 - 4 } & Cukup & 5 & $62.50 \%$ \\
\cline { 2 - 4 } & Kurang & 2 & $25.00 \%$ \\
\hline \multirow{2}{*}{ Teacher mastery of the media } & Baik & 6 & $75.00 \%$ \\
\cline { 2 - 4 } & Cukup & 2 & $25.00 \%$ \\
\hline \multirow{3}{*}{ Teacher skills and creativity } & Baik & 1 & $12.50 \%$ \\
\cline { 2 - 4 } & Cukup & 2 & $25.00 \%$ \\
\cline { 2 - 4 } & Kurang & 5 & $62.50 \%$ \\
\hline Cooperation between teachers & Baik & 8 & $100.00 \%$ \\
\hline \multirow{2}{*}{ Institutional support } & Cukup & 6 & $75.00 \%$ \\
\cline { 2 - 4 } & Kurang & 2 & $25.00 \%$ \\
\hline Coordination of leaders and teachers & Baik & 8 & $100.00 \%$ \\
\hline
\end{tabular}

The results of Survey I, both teachers and parents of students, are used as a reference by schools to make improvements to the system so that service quality improvement which is the main objective can be achieved. The application of TQM is also carried out by schools to improve the quality of education services. Every aspect is observed and analyzed so that the evaluation can make the right decision in improving the service delivery process.

Table 4. Survey Data Normality Test Results I and Survey II

\begin{tabular}{|l|l|l|l|l|l|l|}
\hline \multicolumn{1}{|l|}{ Tests of Normality } \\
\hline
\end{tabular}

To see the extent of the application of TQM to the quality of education services in schools, a statistical analysis is needed. In this case the statistical analysis begins with the Normality Test on each data group (Ia Data and Data II). Because the amount of data is below 100, the Normality Test refers to the Sig. Shapiro-Wilk. Normality Test Results (Table 4) show that the significance value of Ia and Data II data are below the value of $\alpha$ (sig. <0.05) so that both groups of data can be said to have abnormal data distribution. Because the two groups of data were not normally distributed, the statistical analysis continued with Chi Square. 
Table 5. Chi Square Test Results of Survey Data Before Application of TQM and Survey After Application of TQM

\begin{tabular}{|c|c|c|c|}
\hline \multicolumn{4}{|l|}{ Chi-Square Tests } \\
\hline & Value & $\mathrm{df}$ & Asymp. Sig. (2-sided) \\
\hline Pearson Chi-Square & $262.026^{\mathrm{a}}$ & 221 & .030 \\
\hline Likelihood Ratio & 126.446 & 221 & 1.000 \\
\hline $\begin{array}{l}\text { Linear-by-Linear } \\
\text { Association }\end{array}$ & 12.268 & 1 & .000 \\
\hline $\mathrm{N}$ of Valid Cases & 58 & & \\
\hline
\end{tabular}

Chi Square analysis was performed to compare the two averages in the two groups of data so that a significance value was obtained. Based on the data from the Chi Square analysis in Table 5, the Asym value. Sig. obtained was 0.030 (see Table 5). This value is below the value of $\alpha$ (sig. $<0.05$ ), so it can be said that the application of TQM significantly influences the quality of education services in primary schools. The effect is also positive, this is seen from the average score before the application of TQM which amounted to 59.93 (adequate category) increased to 74.45 (good category) after the application of TQM. Therefore, if seen from the value of the analysis shows that the application of TQM in schools can improve the quality of education services. In this case, the quality of educational services in question is distance education services using technology.

\section{DISCUSSION AND CONCLUSIONS}

The quality of educational services in schools can be described from the level of satisfaction of parents of students. This is consistent with Sutarto's statement (2015) that customer satisfaction really determines the quality of service. In this study, an analysis of internal customer needs was conducted by conducting a survey of teachers. While the analysis of external customer needs is done by conducting a survey of parents. Both of these analysis processes can be used to identify deficiencies in the process of implementing learning because they are the main objective (Goetch, 1994; Sutarto, 2015; Dornseif, 1996). Parents of students assess that the TQM armpit has not been implemented, the learning process is not quality. Students are only stuffed with independent assignments with no delivery of material. This problem is synchronous with the problems experienced by teachers, where they feel that the supporting facilities provided by schools are inadequate and their knowledge and mastery of learning media is not good. Schools as institutions respond to this aspect by completing facilities and infrastructures and providing training to teachers so that they can maximize the use of media with high innovations and creativity. Institutional support has also begun to be increased by providing motivation in the form of covering the cost of purchasing quotas and installing internet networks at schools. In general, the obstacles faced were able to be overcome, but the obstacle that still arises until this research is completed is the problem of the internet network. The management has difficulty in overcoming this because it deals with external parties, namely the service provider. This is a form of follow-up to the application of TQM in improving service quality. Because according to Sutarto (2015), facilities and infrastructure as well as cooperation and support between one division and another will be able to improve the quality of service.

In addition, schools as a management-based institution has a role to help organizational behavior related to motivation, productivity, and satisfaction (Ibtasam, 2002; Darmadji, 2008). It also still needs to be done even though environmental conditions are not supportive. Changes in teaching and learning patterns will certainly never be separated from the role of the teacher (Collie, Shapka, \& Perry, 2011; Yusof, 2012; Thien, Abd Razak, \& Ramayah, 2014; Zacharo, Marios, \& Dimitra, 2018), especially changes to online learning patterns. Teachers must be prepared for a variety of learning conditions and student conditions, including the development of life in society (Abdullah, 2016; Darling-Hammond \& John Bransford, 2005; Zein, 2016). However, teacher readiness is inseparable from the support of schools as institutions and parents as partners in educating children.

Education is a vehicle through which students develop their potential in an educational process that is in line with educational goals. Therefore, it becomes a natural thing if the community demands the availability of "good school" which is reflected in the effectiveness of the performance of the school concerned. As an educational institution, schools should place the essence of education as a priority concern in its administration, where education is interpreted as a human effort to foster their personality, both in terms of physical development, intellect, and soul in accordance with values in society and culture. in a sustainable manner, so that maturity and independence are formed to live in the midst of society. The key to overcoming these barriers is the existence of good communication and socializing system changes 
to all parties involved so as to build commitment and empower the work team (Darmadji, 2008). The party responsible for this domain is the top-level manager, the school principal (Sumiati and Niemted, 2020).

Thus, based on the description above it can be said that the application of TQM is able to improve the quality of education services in primary schools during the COVID-19 pandemic. This can be seen from the increase in the mean value of the parents' assessment of the quality of long distance learning and teaching before and after the implementation of TQM, its value increased from 59.93 to 74.45. In addition, statistical analysis also shows that the application of TQM has a significant effect in improving service quality.

\section{REFERENCES}

Aderholt, R. (2020, March 22). Coronavirus outbreak shining an even brighter light on internet disparities in rural America. The Hill. https://thehill.com/blogs/congress-blog/technology/488848coronavirus-outbreak-shining-an-even-brighter-light-on

Anderson, J. (2020, March 4). Should schools close when coronavirus cases are still rare?. Quartz. https://qz.com/1810224/does-closing-schools-protect-kids-and-us-from-coronavirus/

Arcaro, J. (1995). Quality in Education, An Implementation Handbook. St. Lucie Press

Arikunto (2016). Prosedur Penelitian: Suatu Pendekatan Praktik. Rineka Cipta.

Bali, M.M.E.I. (2019). Implementasi Media Pembelajaran Berbasis Teknologi Informasi dan Komunikasi dalam Distance Learning. Tarbiyatuna: Kajian Pendidikan Islam, 3(1), 29-40. https://doi.org/10.29062/tarbiyatuna.v3i1.198

Bank, J. (1992). The Essencs of Total Quality Management. Prentice Hall.

Bounds, R. et al. (1994). Beyond Total Quality Management. McGraw-Hill, Inc.

Cavanaugh, C., Dawson, K., \& Ritzhaupt, A. (2011). An evaluation of the conditions, processes, and consequences of laptop computing in K-12 classrooms. Journal of Educational Computing Research, 45(3), 359-378. https://doi.org/10.2190\%2FEC.45.3.f

ChanLin, L. J. (2008). Technology integration applied to project-based learning in science. Innovations in Education and Teaching International, 45(1), 55-65. https://doi.org/10.1080/14703290701757450

Collie, R. J., Shapka, J. D., \& Perry, N. E. (2011). Predicting teacher commitment: The impact of school climate and social-emotional learning. Psychology in the Schools, 48(10), 1034-1048. https://doi.org/10.1002/pits.20611

Darmadji, A. (2008). Implementasi Total Quality Management sebagai Upaya Peningkatan Mutu Pendidikan di MAN Model Yogyakarta. El Tarbawi: Jurnal Pendidikan Islam, 2(1), 181 - 200. https://doi.org/10.20885/tarbawi.vol1.iss2.art3

Dornseif, A. (1996). School-Based Management. Association for Supervision \& Curriculum Development (ASCD).

George, S. \& Weimerskirch, A. (1994). Total Quality Management: Strategies and Techniques Proven at Today's Most Successful companies. John Wiley \& Sons, Inc.

Glazer, E., \& Hannafin, M. (2008). Factors that influence mentor and teacher interactions during technology integration collaborative apprenticeships. Journal of Technology and Teacher Education, 16(1), 35-61. https://www.learntechlib.org/primary/p/22797/

Glazer, E., Hannafin, M. J., \& Song, L. (2005). Promoting technology integration through collaborative apprenticeship. Educational Technology Research and Development, 53(4), 57-67. https://www.learntechlib.org/p/67718/

Goetsch, D. \& Davis, S. (2014). Quality Management for Organizational Excellence: Introduction to Total Quality (Seventh Edition). Pearson.

Harris, J. L., Al-Bataineh, M. T., \& Al-Bataineh, A. (2016). One-to-one technology and its effect on student academic achievement and motivation. Contemporary Educational Technology 7 (4), 368-381. https://doi.org/10.30935/cedtech/6182

Horn, M. B. (2020, March 23). COVID-19's long-term impacts on education in 2020 and beyond. EdSurge. https://www.edsurge.com/news/2020-03-23-covid-19-s-long-term-impacts-on-education-in2020 -and-beyond

Ibtasam, A. (2002). School Based Mangement. Logos.

Ismajli, H., Bytyqi-Damoni, A., Shatri, K., and Ozogul, G. (2020). Coaching teachers to integrate technology: The effects of technology integration on student performance and critical thinking. Ilkogretim Online - Elementary Education Online 19(3), 1306-1320. http://ilkogretimonline.org.tr/index.php/io/article/view/3911 
Jang, S. (2010). Integrating the interactive whiteboard and peer coaching to develop the TPACK of secondary science teachers. Computers \& Education, 55(4), 1744-1751. https://doi.org/10.1016/j.compedu.2010.07.020

Shereen, M.A., Khan, S., Kazmi, A., Bashir, N., \& Siddique, R. (2020). COVID-19 infection: Origin, transmission, and characteristics of human coronaviruses. Journal of Advanced Research, 24, 9198. https://doi.org/10.1016/j.jare.2020.03.005

Kuşçu, M. \& Arslan, H. (2015). Evaluation of effectıveness of vitamın teacher portal. European Scientific Journal 11(10), 226-239. https://eujournal.org/index.php/esj/article/download/5421/5317

Lever-Duffy, J. \& McDonald, J. B. (2008). Teaching and learning with technology (3rd Edition). Pearson Education.

Lin, Q., Zhao, S., Gao, D., Lou, Y., Yang, S., Musa, S. S., Wang, M. H., Cai, Y., Wang, W., Yang, L., \& He, D. (2020). A conceptual model for the coronavirus disease 2019 (COVID-19) outbreak in Wuhan, China with individual reaction and governmental action. International Journal of Infectious Diseases, 93, 211216. https://doi.org/10.1016/j.ijid.2020.02.058

Mahase, E. (2020). Covid-19: WHO declares pandemic because of "alarming levels" of spread, severity, and inaction. BMJ (Clinical Research Ed.), 368(1036). https://doi.org/10.1136/bmj.m1036

Muhson, A. (2010). Pengembangan Media Pembelajaran Berbasis Teknologi Informasi. Jurnal Pendidikan Akuntansi Indonesia, 3(2), 1 - 10. https://doi.org/10.21831/jpai.v8i2.949

Mukhopadhyay, M. (2005). Total Quality in Education. Sage Publication.

Niess, M. (2005). Preparing teachers to teach science and mathematics with technology: Developing a technology pedagogical content knowledge. Teaching and Teacher Education, 21(2005), 509-523. https://doi.org/10.1016/j.tate.2005.03.006

Sallis, E. (2006). Total Quality Management in Education. Kogan Page Ltd.

Spears, S. A. (2012). Technology-enhanced learning: The effects of 1: 1 technology on student performance and motivation. The University of West Florida.

Sumiati and Niemted, W. (2020). The impact of instructional leadership on Indonesian elementary teacher efficacy. Ilkogretim Online - Elementary Education Online 19 (4), 2335-2346. http://ilkogretim-online.org.tr/index.php/io/article/download/3938/2840

Sutarto (2015). Manajemen Mutu Terpadi (MMT-TQM) Teori dan Penerapan di Lembaga Pendidikan. UNY Press.

Temelli D., Şahin C. , and Kartal O.Y. (2020). Teachers' opinions on the effectiveness of digital technology in the realization of cognitive objectives. Ilkogretim Online - Elementary Education Online 19(4), 2448 - 2466. http://ilkogretim-online.org.tr/index.php/io/article/view/3801

Thien, L. M., Razak, A., N., \& Ramayah, T. (2014). Validating teacher commitment scale using a Malaysian sample. SAGE Open, 4(2), 1-9. https://doi.org/10.1177\%2F2158244014536744

Tjiptono F. \& Diana A. (2000). Total Quality Management. ANDI.

UNESCO. (2020). Motivating learners during remote learning due to COVID-19 - Tips for teachers (p. 1). UNESCO. https://hivhealthclearinghouse.unesco.org/library/documents/motivating-learnersduring-remote-learning-due-covid-19-tips-teachers

Wahyono P., Husamah H, dan Budi A.S. (2020). Guru profesional di masa pandemi COVID-19: Review implementasi, tantangan, dan solusi pembelajaran daring. Jurnal Pendidikan Profesi Guru, 1(1), 51 - 65. https://doi.org/10.22219/jppg.v1i1.12462

Watkins, J. (2020). Preventing a covid-19 pandemic. The BMJ, 368, 1-2. https://doi.org/10.1136/bmj.m810

World Health Organization. (2020). Key messages and actions for COVID-19 prevention and control in schools (L. Bender (ed.); Issue March). UNICEF. https://www.who.int/publications/m/item/keymessages-and-actions-for-covid-19-prevention-and-control-in-schools

Yan, W. (2020, March 17). How will COVID-19 impact global education?. China Daily. http://www.chinadaily.com.cn/a/202003/17/WS5e7045e9a31012821727fb8b.html

Yusof, N.M. (2012). School climate and teachers' commitment: A case study of Malaysia. International Journal of Economics Business and Management Studies, 1(2), 65-75. https://ssrn.com/abstract=2151470

Zacharo, K., Marios, K., \& Dimitra, P. (2018). Connection of teachers' organizational commitment and transformational leadership. A case study from Greece. International Journal of Learning, Teaching and Educational Research, 17(8), 89-106. https://doi.org/10.26803/ijlter.17.8.6

Zein, M. (2016). Peran guru dalam pengembangan pembelajaran. Journal UIN- Alauddin, 5(2), 274-285. https://doi.org/10.24252/ip.v5i2.3480 
Zhang, W., Wang, Y., Yang, L., \& Wang, C. (2020). Suspending classes without stopping learning: China's education emergency management policy in the COVID-19 outbreak. Journal of Risk and Financial Management, 13(3), 55. https://ideas.repec.org/a/gam/jjrfmx/v13y2020i3p55-d332192.html 